\title{
The Potential of Agroforestry in Supporting Food Security for Peatland Community - A Case Study in the Kalampangan Village, Central Kalimantan
}

\author{
Afentina ${ }^{{ }^{*}}$, Yanarita ${ }^{1}$, Lies Indrayanti', Johanna Angga Rotinsulu', \\ Nisfiatul Hidayat ${ }^{1}$, Jenni Sianipar ${ }^{2}$ \\ 1 Faculty of Agriculture, Palangka Raya University, Jl. H. Timang, Palangka Raya Central Kalimantan, 73112, \\ Indonesia \\ 2 Student at Forestry Department, Faculty of Agriculture, Palangka Raya University, Jl. Garuda XA No. 12, \\ Palangka Raya Central Kalimantan, 73112, Indonesia \\ * Corresponding author's e-mail: afentina.unpar@gmail.com
}

\begin{abstract}
Food security is one of the main problems under the pandemic and climate change condition that we currently face. Managing peatland to fulfill community needs faces several problems including peat fire, GHG emissions and loss of biodiversity. Agroforestry is one of land use systems on peatland that is capable of accommodating different interests while still concerning the conservation purposes. This study aimed to assess the potential of agroforestry for ensuring the food security of local communities. This research was carried out in the Kalampangan Village, Palangka Raya City central Kalimantan for six months. This study used both quantitative and qualitative approaches, including interviews and field observations. Interviews were carried out with 13 farmers in Kalampangan who applied an agroforestry system. The data gathered included all agroforestry components and number of the food production component. The data were analyzed using descriptive statistics. The results showed three agroforestry types were applied by the Village community Kalampangan, namely agrosilviculture, agrosilvopasture, and agrofisheries. The biodiversity of agroforestry in Kalapangan is relatively high, with a total of 58 different species identified. A total of $86 \%$ of all agroforestry components are sources of food, including fruits, vegetables, seeds, tubers, spices and livestock. The information above shows that the peatland agroforestry in the Kalampangan Village has the potential to support food security while maintaining the biodiversity. Thus, agroforestry can be recommended as a peatland land use and rehabilitation strategies to accommodate the basic needs of local communities and increasing their prosperity.
\end{abstract}

Keywords: peatland, agroforestry, food security, local communities.

\section{INTRODUCTION}

The peatland in Central Kalimantan plays an important role both in the ecological and economic aspects. Peatland is home for vast biodiversity and many of them are endangered species, including Sumatran tiger, Asian Elephants and Orangutan [Gaveau et al., 2009; Simamora, 2010]. In addition peatland is considered as principal carbon sink. The estimated aboveground carbon stock on peatland is $230 \pm 66 \mathrm{Mg} \mathrm{C} / \mathrm{ha}$, while the carbon stored in peat soil organic soil is even greater, reaching $2425 \pm$
$726 \mathrm{Mg} \mathrm{C} / \mathrm{ha}$. Therefore, degradation of peatland was calculated as a major source of Green House Gases (GHGs) emission and became the main target for conservation project in Central Kalimantan. In terms of economic significance, peatland has supported livelihood of local communities for centuries. For instance, the peatland ecosystem provides a source of food and timber for construction or various non-timber forest products.

However, the Indonesia peatlands, especially in Central Kalimantan has been under pressure and degraded for more than three decades. Illegal 
logging, clearing forests for logging, large scale agriculture, opening road access and construction of drainage canal damaged the peatlands. Furthermore, these activities resulted in degradation of peatlands and triggered forest fires [Murdiyarso et al., 2010; Miettinen et al., 2016; Osaki et al., 2016]. Apart from these ecological disasters, incorrect peatland management also has a major impact on the livelihoods of local communities in which their food security depends largely on the natural resources [Laterra et al., 2012; Law et al., 2015]. Therefore, utilization of peatland for the production system should be conducted wisely and take the ecological aspect into account.

The food security is an important issue currently [Waldron et al., 2017]. The COVID-19 pandemic conditions, climate change and natural resources decrease should be anticipated by strengthening the resilience of local communities. In general, rural communities have limited resources as well as access to technology and food supply. Therefore, strengthening the ability of local communities to provide food for households and surrounding community is important. Agroforestry can offer a solution for these challenges and assessing the potential of agroforestry systems to support food security is a critical step.

Agroforestry has been applied for centuries to optimize land production by combining several components to meet the farmers' needs and also preserve the natural resources [Food and Agriculture Organization of United Nations [FAO], 2015; Godfray et al., 2010]. Agroforestry is also developed to solve problems of marginal land and rural development. By adopting agroforestry, elevating community welfare can be done without sacrificing natural resources and environment [Charles et al., 2013; Garrity et al., 2010; Thorlakson \& Neufeldt, 2012]. Therefore, the community becomes the most important factor for agroforestry management and agroforestry systems.

Agroforestry is a manmade ecosystem that combines forest and/or agriculture and/or fishery and livestock through cultivation which incorporates various ecosystem elements into space and time in natural ecosystem [Garrity et al., 2010; Nair, 1993; Pretty \& Bharucha, 2014]. Divers agroforestry models have been implemented in various rural areas of Indonesia since the ancient times, including shifting cultivation, home garden and agroforestry. These models can also be developed at various scales (household, village, and subdistrict, district, provincial and national) and made agroforestry ideal for multiple purposes, including provision of food security. This research aimed to analyze the potential of agroforestry in the Kalampangan Village to support food security.

\section{MATERIAL AND METHODS}

\section{Research Location and Time}

This research was conducted in the Kalampangan Village, Palangka Raya City, Central Kalimantan Province. The time for compiling and planning the research was six months from July 2020 - January 2021. The Kalampangan Village was chosen, because the local government started developing agroforestry as land use system on peat land as an alternative to monoculture system. The Kalampangan village is well known as a food production village, where the majority of the farmers cultivate vegetables on peatland using the monoculture system. By implementing agroforestry, government intended to give example how to minimize the negative impact of cultivation on peat land while maintaining food production.

\section{General Condition of the Kalampangan Village}

The Kalampangan Village is located in the Sebangau subdistrict within the Palangka Raya City. The Kalampangan Village is located approximately $18 \mathrm{~km}$ west of the Palangka Raya City, which can be reached by car. The area of the Kalampangan Village is $46.25 \mathrm{~km}^{2}(5,000 \mathrm{Ha})$. It includes a residential area of $420 \mathrm{Ha}$, plantations of 1,000 Ha, yards of 3,544 Ha, offices of $20 \mathrm{Ha}$ and other infrastructure of $16 \mathrm{Ha}$ [Kalampangan Agricultural Extension Center, 2020].

Geographically, the Kalampangan Village is located between $113^{\circ} 58^{\prime} 20-144^{\circ} 03^{\prime} 50$ East Longitude and $2^{\circ} 16^{\prime} 00-2^{\circ} 19^{\prime} 20$ '"South Latitude. The topography of the Kalampangan Village is flat with a slope of $0-3 \%$. Meanwhile, altitude ranges from 14 to 18 meters above sea level [Kalampangan Agricultural Research Institute, 2020].

The Kalampangan Village is an area with a tropical climate which is influenced by rainy and dry seasons. The average temperature is $24-34{ }^{\circ} \mathrm{C}$, with average rainfall $2000-3000 \mathrm{~mm}$ per year. The rainy season occurs in November - February, while the dry season occurs in June - September [Kalampangan Agricultural Extension Center, 2020]. The Kalampangan Village has a male population 
of 2,110 people, and a female population of 2,043. The number of male population is greater than the total female population. The total population in Kalampangan Village is 4,153 people with a total of 1,266 families [BPS Kota Palangka Raya, 2020].

\section{Data Collection}

The main data in this research comprised agroforestry patterns, agroforestry components (perennial crops, agricultural crops, fish or livestock) and number of agroforestry components as the source of food. The data were collected by using the interview and field observation methods. Field observations were conducted using direct observation on 13 agroforestry system. The observations were also accompanied by interviews with the owner of the agroforestry system (13 respondents).

The analysis was carried out both quantitatively and qualitatively. The quantitative data analysis uses descriptive statistical data analysis to determine the number of agroforestry components and the percentage of food source. The quantitative analysis is used to analyze the results of interviews to determine the applied agroforestry pattern.

\section{RESULT AND DISCUSSION}

\section{Profile of interviewed respondents}

The 10 respondents were Javanese, two respondents are from the Dayak Tribe, and one respondent from the Banjar Tribe. Most respondents were in age range of 41-64 years and only about $31 \%$ were in age range of $28-40$ years and $23 \%$ were over 65 years old. The education level shows 31\% have elementary education, $31 \%$ junior high school, $31 \%$ high school and $8 \%$ tertiary education. Most respondents managed land with an agroforestry system of 0.5 ha or less and only $38 \%$ had $0.6-2$ ha of land and $8 \%$ managed agroforestry land of more than 2 ha. The respondents were interested in implementing an agroforestry system, because they saw the success of one of respondents in its implementation. In addition, they collectively receive assistance from Plantation and Agriculture Department.

\section{Agroforestry Components}

On the basis of the observation and interviews with 13 families (households) in the Kalampangan Village who manage their land using agroforestry system, it was found that there are 58 different species consisting of vegetables, fruits, seeds, tubers, woody plants and animal feed. Table 1 shows the detail component of agroforestry.

In total, 58 different species were indentified in the agroforestry system in Kalampangan, which indicate that this system could maintain biodiversity. The entire agroforestry component could be classified into seven categories: vegetable, fruit, source of carbohydrate, spice, whole grain, woody, source of protein and fodder. Taking into account the number of species for each category, it can be seen that vegetables and fruits dominated the system. Meanwhile, woody species accounted only for $10.34 \%$. The list of the component from the Table 1 indicates that even though the land cultivated using agroforestry system, it does not lose their functions as a food production system.

This research found that the biodiversity and variability of food production cycle in agroforestry system relatively higher. Most of the vegetable farms in the Kalampangan village only consist of five out of ten components. Majority of farmers in Kalampangan cultivate vegetables that have high demand from the local market, for example spinach, long bean, egg plan, chili and leek. This type of vegetation does not require long time to be harvested. On average, they could be harvested in 20 until 30 days. Monoculture and short time period of harvest are consistent with the characteristic of the most farmers in Kalampangan. In general, they do not have sufficient capital and need immediate cash to cover their daily expenses. As consequences commodities that have short time and low input are the most suitable for their condition.

The food usage in Kalampangan is still conventional. Apart from being consumed directly, this food is also commercialized without any diversification activities. Almost $90 \%$ of total types of forest food commodities are consumed and marketed without any processing activity, while the remaining $10 \%$ are processed before being consumed or marketed. Several types of commodities are sold immediately after harvest, such as bananas, dragon fruit, rambutan, jackfruit, and others. The palm product goes to post-harvest processing stages. It can be commercialized in form of products such as brown sugar. The diversification development of local food processing is seen as a strategic step to support food security, especially in relation to the promotion of diverse food availability, overcoming nutritional problems and empowering the community's economy. Table 2 shows the food source agroforestry components. 
Table 1. Component of agroforestry in the Kalampangan village

\begin{tabular}{|c|c|c|}
\hline No. & Types of agroforestry crops & Latin name \\
\hline \multicolumn{3}{|c|}{ Vegetable } \\
\hline 1 & Leek & Allium fistulosum \\
\hline 2 & Chili & Capsicum frutescens \\
\hline 3 & Eggplant & Solanum melongenae \\
\hline 4 & Chayote & Sechium edule \\
\hline 5 & Tomato & Lycopersicon esculentum \\
\hline 6 & Long Beans & Vigna sinensis \\
\hline 7 & Petai & Parkia speciose \\
\hline 8 & Jengkol & Pitecelobium jiringa \\
\hline 9 & Sweet vegetables & Brassica chinensis var. Parachinensis \\
\hline 10 & Spinach & Amaranthus \\
\hline 11 & Kale & Ipomoea reptana \\
\hline 12 & Dutch corn & Zea mays \\
\hline 13 & Bitter melon & Momordica charantia \\
\hline 14 & Cucumber & Cucumis sativus \\
\hline 15 & Celery & Apium graveolens var. Dulce \\
\hline 16 & Bean & Phaseolus vulgaris \\
\hline 17 & Basil & Ocimum sanctum \\
\hline \multicolumn{3}{|c|}{ Fruit } \\
\hline 18 & Water apple & Psidium guajava \\
\hline 19 & Avocado & Persea Americana \\
\hline 20 & Mango & Mangifera indica \\
\hline 21 & Durian & Durio zibethinus \\
\hline 22 & Banana & Musa sp. \\
\hline 23 & Guava & Psidium guajava \\
\hline 24 & Jackfruit & Artocarpus heterophyllus \\
\hline 25 & Papaya & Carica papaya \\
\hline 26 & Betel nut & Areca catechu \\
\hline 27 & Rambutan & Nephelium lappaceum \\
\hline 28 & Dragon fruit & Selenicereus undatus \\
\hline 29 & Coconut & Cocos nucifera \\
\hline 30 & Soursop & Annona muricata \\
\hline 31 & Melon & Cucumis melo \\
\hline 32 & Pineapple & Ananas comosus \\
\hline 33 & Orange & Citrus \\
\hline 34 & Watermelon & Citrullus lanatus \\
\hline 35 & Longan & Dimocarpus longan \\
\hline 36 & Passion fruit & Passiflora edulis \\
\hline \multicolumn{3}{|c|}{ Source of carbohydrate } \\
\hline 37 & Taro & Colocasia esculenta \\
\hline 38 & Cassava & Manihot esculenta Crantz \\
\hline \multicolumn{3}{|c|}{ Spice } \\
\hline 39 & Turmeric & Curcuma domestica \\
\hline 40 & Laos & Languas galangal \\
\hline 41 & Ginger & Zingiber offiinale \\
\hline 42 & Galangal & Kaempferia galangal \\
\hline 43 & Lemongrass & Cymbopogon citratus \\
\hline
\end{tabular}


Table 1. Cont. Component of agroforestry in the Kalampangan village

\begin{tabular}{|c|c|c|}
\hline \multicolumn{3}{|c|}{ Whole grains } \\
\hline 44 & Coffee & Coffea robusta \\
\hline 45 & Pepper & Piper nigrum \\
\hline \multicolumn{3}{|c|}{ Woody } \\
\hline 46 & Sengon & Albizia falcataria \\
\hline 47 & Jelutung & Dyera lowii \\
\hline 48 & Gaharu & Aquilaria moluccensis \\
\hline 49 & Gerunggang & Cratoxylum formosum \\
\hline 50 & Balangeran & Shorea bal Pangeran \\
\hline 51 & Aren & Arenga pinnata \\
\hline \multicolumn{3}{|c|}{ Source of Protein } \\
\hline 52 & Chicken & Gallus gallus domesticus \\
\hline 53 & Cow & Taurus boss \\
\hline 54 & Pig & Sus \\
\hline 55 & Fish & Pisces \\
\hline 56 & Goat & Capra aegagrus hircus \\
\hline 57 & Duck & Anas platyrhynchos \\
\hline \multicolumn{3}{|c|}{ Fodder } \\
\hline 58 & Elephant grass & \\
\hline
\end{tabular}

On average, $86 \%$ of all agroforestry components are a source of food. This indicates that agroforestry has large potential to support family food security. Most of food sources are cultivated in the form of agricultural crops as vegetables, fruits and tubers. The community has not yet cultivated the rice plant as the staple food. Rice is bought at a nearest shop or market.

The dominance of agricultural crops as food producers in agroforestry, both in terms of quantity of space, indicates that the farmers in the
Kalampangan Village are developing agroforestry to provide food supply. The agroforestry system is an option to maximize the production capacity of farmers land by intercropping combining woodtimber and agricultural crops, cattle and fish.

Various types of food produced by agroforestry at research location can have an influence on variation in food needs in the Kalampangan Village. The higher the diversity of food types cultivated on land will provide an opportunity for fulfillment of food needs based on its type. Species diversity

Table 2. Percentage of food source component for each respondent

\begin{tabular}{|c|c|c|c|c|}
\hline No. & Respondents & $\begin{array}{c}\text { Agroforestry } \\
\text { Components }\end{array}$ & $\begin{array}{c}\text { Food Sources } \\
\text { Components }\end{array}$ & $\begin{array}{c}\text { Food crop types in agroforestry } \\
\text { gardens (\%) }\end{array}$ \\
\hline 1 & Sarjono & 21 & 18 & 85.71 \\
\hline 2 & Sumariyanto & 19 & 17 & 89.47 \\
\hline 3 & Suwito & 25 & 22 & 88.00 \\
\hline 4 & Andri & 18 & 15 & 83.33 \\
\hline 5 & Mardian & 23 & 22 & 95.65 \\
\hline 6 & Sutekno & 30 & 26 & 86.67 \\
\hline 7 & Supirno & 22 & 18 & 81.82 \\
\hline 8 & Sunaryo & 20 & 18 & 90.00 \\
\hline 9 & Oggy & 11 & 7 & 63.64 \\
\hline 10 & Mardi & 23 & 21 & 91.30 \\
\hline 11 & Sabriani & 29 & 26 & 89.66 \\
\hline 12 & Ahmad T & 33 & 30 & 90.91 \\
\hline 13 & Unjila & 28 & 25 & 89.29 \\
\hline & Average & 23.23 & 20.38 & 86.57 \\
\hline
\end{tabular}


describes the entire scope of ecological adaptation, where the plant species diversity is a biological resource and an alternative resource for humans.

The contribution of agroforestry land to food security for communities around agroforestry land is more significant. They not only provide staple food to overcome the food shortages but also cultivate various other types of food to fulfill other needs [Luni and Lal, 2011]. Likewise, most of the people in the Kalampangan Village are managed with aim to meet the food need, the plants are cultivated for short and long term fulfillment.

The present of trees such as Jelutung, Belangeran and Aren support conservation of peatland. Cultivation on peatland is quite challenging, because it should take into account both economic and conservation considerations. Jelutung and other endemic species of peatland ecosystem prevent it from degradation. Trees provide shade, maintaining the microclimate that is paramount in maintaining the water content of peatland. Preserving micro climate is also essential in creating favorable conditions for soil macro- and microorganisms which necessary for soil fertility.

Parennial vegetation comprises fruit tree or timber tree can be considered as investment, since they offer long term income. Fruit trees, such as mango or orange, can produce yield 5 years after being planted and then generate annual income. Sengon can be cut and sold for timber after five until seven years. However, this kind of investment is not suitable for poor farmers.

\section{Agroforestry Pattern}

The interview with farmers revealed that the community's understanding of the agroforestry pattern is very limited. Most farmers still depend highly on crops production. The farmers prefer more profitable and easy care plants. The aspects that influence the farmers' decision to implement agroforestry are the feasibility, profitability, revenue, acceptability and sustainability. The aspects of land management ease are based on ability of farmers to work / manage land. It is proven by their mastery in technology. They can cultivate the land optimally with simple methods. The profitability aspect is based on farmer's ability to produce more than one kind of product. One land is planted at least four types of seasonal crops and two types of annual crops / trees. There is a time gap between planting and harvesting the product.
The acceptability aspect based on farmers benefits in agroforestry systems is larger than other systems, such as selling the gasoline, pungent bulb and other fried foods. This aspect includes the calculation of risk, flexibility to gender roles, conformity with local culture and compatibility with other businesses. Furthermore, the sustainability aspect is based on the utilization of land from agroforestry to provide continuity results throughout the year. The rainy season is very helpful in watering the plants and dry season watering is done by borehole / drains else in garden.

On the basis of types of the components, the agroforestry in the Kalampangan village can be grouped into three major groups, namely agrosilviculture, agrosilvopastura and agrosilvofisheries.

\section{Agrosilviculture}

Agrosilviculture patterns are developed by some farmers in the Kalampangan Village. This pattern consists of a combination of forestry and agricultural crops. On the basis of forestry plants types, this agrosilviculture pattern can be differentiated into sengon-based agrosilviculture, jelutong-based agrosilviculture and belangiran-based agrosilviculture. Jelutung and Belangiran are endemic forestry plants for peatlands. Jelutung is cultivated for its latex, while belangiran is a construction wood material which has high economic value. The price of striped boards per meter cubic is approximately Rp. I million. Jelutung agroforestry has an important economic function for rural communities, especially for the Kalampangan Village. Jelutung agroforestry can provide economic and ecological benefits to increase the soil fertility to maximize the plant growth. Sengon tree is an introduced plant of fast growing species used for raw material, i.e. paper and light construction. Figure 1 shows the combination of sengon tree and dragon fruit.

The interview with the farmers revealed that the tree species planted among crops fulfill at least three criteria. First, the tree should have economic value, could be derived from the fruits, timber or latex. Secondly, canopy of the tree is not too dense, allowing the sun light to reach crops that live at the low strata. Third, the trees do not transmit the allelopathy compound that could prevent the growth of crops.

In order to maximize the mutual symbiosis between trees and crops and minimize the competition, the agroforestry in Kalampangan follows a certain pattern. In some locations, agroforestry managed following alley cropping. Trees are planted in a row and crops are planted between 


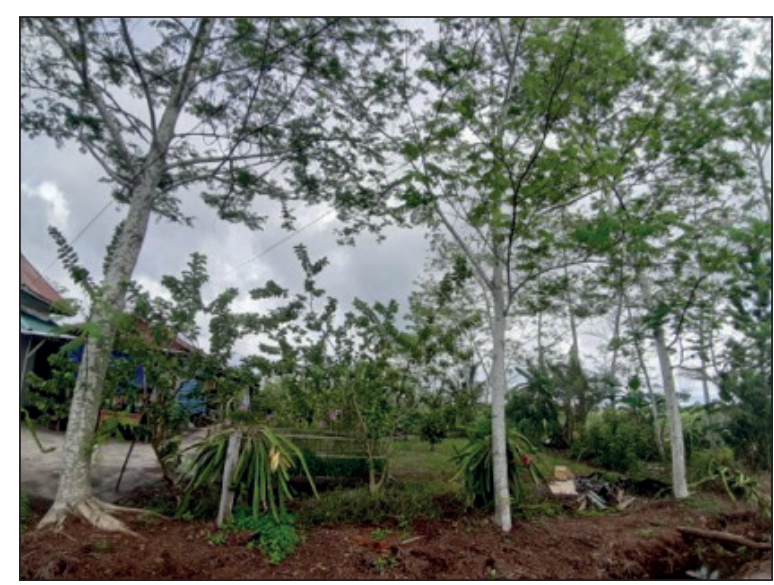

Figure 1. Combination of Sengon Tree and Dragon Fruit

the rows. In some other places, trees are planted in the border, surrounding the farming area. The farmers tend to choose the first pattern, since the tree benefited from crop fertilizer.

Agricultural crops cultivation includes corn, tomatoes, chilies and eggplant. Combination between perennial trees with crop provides farmers with short and long term income. Figure 2 shows the combination of jelutung and maize.

\section{Agrosilvopastura}

The agrosilvopastura pattern has a mixture of forestry, agriculture and livestock crops. The farmers plant the woody plant of Sengon (Paraserianthes falcataria), Balangeran (Shorea balangeran), Jelutung (Dyera lowii), Gerunggang and acacia (Acacia mangium). The seasonal plants are Mustard (Brassica parachinensis), Tomato (Solanum lycopersicumm), Chili (Capsicum frutescens), Long Beans (Vigna Unguiculata sp), Cucumber (Cucumis sativus), Banana (Musa paradisiaca), Watermelon (Citrullus lanatus), Papaya (Carica papaya L.), Kale (Ipomoea aquatica), Beans, Eggplant (Solanum melongena), Spinach (Amaranthus spp), Corn (Zea mays), Pare (Momordica charantia), kencur, bitter melon, celery, turmeric, jackfruit, fruit dragons, oranges, and turmeric whereas livestock comprises cows, ducks, pigs and chickens.

\section{Agrosilvofishery}

Agrosilvofishery is a combination of woody components (forestry) with agriculture and fisheries on same land. The component of crops including bananas, cassava and woody plant is sengon. Farmers choose catfish to due to its properties, i.e ease of maintenance, resistance to diseases and fast growth.

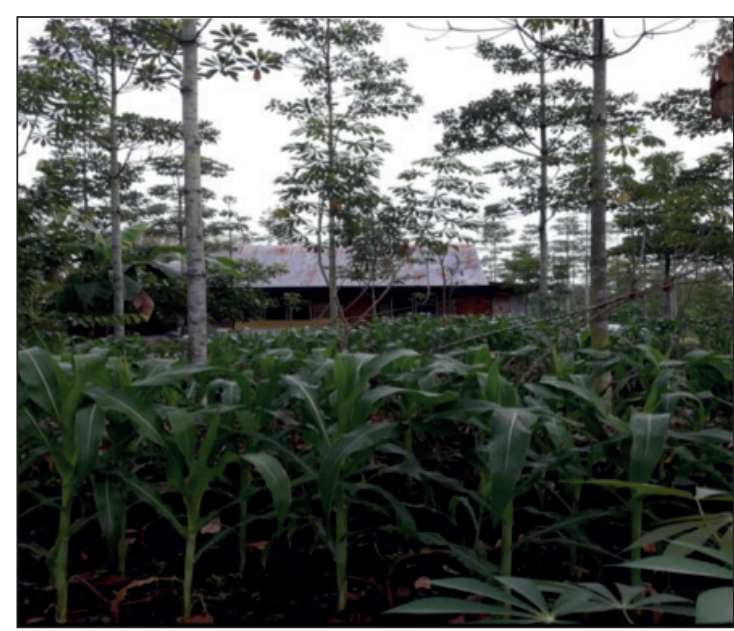

Figure 2. Combination of Jelutung and maize

In addition, the demand for catfish is also relatively high; farmers can sell the fish at the market without any constraint. The price for one kilogram catfish ranged between Rp. 18.000 until Rp. 30.000. Besides selling the fish at the market, vegetables and fruit are utilized for subsistence.

The selection of fish that can be cultivated in peatland is very limited. This is because peatland has low $\mathrm{pH}$. Without any treatment for increasing the $\mathrm{pH}$ and saluted oxygen, only endemic fish can live in peatland water.

The trees in the system play an important role providing shade, thus creating ideal environment for fish to grow. Such trees as Sengon also help maintaining soil fertility, due to its properties that can symbiosed with Nitrobacter which capture the nitrogen from the atmosphere and release it to the soil.

\section{CONCLUSIONS}

Some of the community in the Kalampangan Village manages their land using agroforestry system as an alternative to the monoculture system that is commonly practiced. This research found three different types of agroforestry, namely agrosilviculture, agrosilvopasture and agrosilvofisheries. Integrating trees or cattle or fish into crops farming showed the capability of agroforestry in supporting food security. In addition, incorporating different component generates various sources of food.

\section{Acknowledgements}

This manuscript is part of student thesis of Department of Forestry, Faculty of Agriculture, Palangka Raya University, under the guidance of 
advisor, facilitated by International Center for Research Agroforestry (ICRAF). Thanks are addressed to the Indonesian Country Program / BAR Peat Project World Agroforestry Center Bogor which has supported and funded the author in publishing this Research Paper, and to the Department of Forestry, Faculty of Agriculture, and University of Palangka Raya who has given confidence to guide students in completing the Bachelor level (forestry).

\section{REFERENCES}

1. Balai Penyuluhan Pertanian Kalampangan. 2020. Letak Geografis Kelurahan Kalampangan. Kalampangan. Palangka Raya.

2. BPS Kota Palangka Raya. 2020. Keadaan Penduduk Kelurahan Kalampangan. Kalampangan. Palangka Raya.

3. Charles, R., Munishi, P., Nzunda, E. 2013. Agroforestry as adaptation strategy under climate change in Mwanga District, Kilimanjaro, Tanzania. International Journal of Environmental Protection, 3, 29-38.

4. Food and Agriculture Organization of the United Nations, International Fund for Agricultural Development, \& World Food Programme (2015). The state of food insecurity in the world 2015. Meeting the 2015 International hunger targets: Taking stock of uneven progress. Rome, Italy: FAO.

5. Garrity, D.P., Akinnifesi, F.K., Ajayi, O.C., Weldesemayat, S.G., Mowo, J.G., Kalinganire, A., Bayala, J. 2010. Evergreen agriculture: A robust approach to sustainable food security in Africa. Food Security, 2, 197-214.

6. Gaveau D.L.A, Wich S., Epting J., Juhn D., Kanninen M., Leader-Williams N. 2009. The future of forests and orangutans (Pongo abelii) in Sumatra: predicting impacts of oil palm plantations, road construction, and mechanisms for reducing carbon emissions from deforestation. Environmental Research Letters, 4, 11.
7. Godfray, H., Beddington, J., Crute, I., Haddad, L., Lawrence, D., Muir, J.F., Toulmin, C. 2010. Food security: The challenge of feeding 9 billion people. Science, 327, 812-818.

8. Murdiyarso, D., Hergoualc'h, K., Verchot, L.V. 2010. Opportunities for reducing green-house gas emissions in tropical peatlands. Proc. Natl. Acad. Sci, 107 (46), 19655-19660.

9. Miettinen, J., Shi, C., Liew, S.C. 2016. Land cover distribution in the peatlands of peninsular Malaysia, Sumatra and Borneo in 2015 with changes since 1990. Global Ecology and Conservation, 6, 67-78.

10. Nair, P. 1993. An introduction to agroforestry. Dordrecht, The Netherlands: Springer Science and Business Media.

11. Osaki, M., Nursyamsi, D., Noor, M., Segah, H. 2016. Peatland in Indonesia. Tropical Peatland Ecosystems. Springer, Japan.

12. Laterra, P., Orúea, M.E., Boomana, G.C. 2012. Spatial complexity and ecosystem services in rural landscapes. Agric. Ecosyst. Environ, 154, 56-67.

13. Law, E.A., Bryan, B.A., Meijaard, E., Mallawaarachchi, T., Struebig, M., Wilson, K.A. 2015. Ecosystem services from a degraded peatland of Central Kalimantan: implications for policy, planning, and management. Ecol. Appl, 25(1), 70-87.

14. Pretty, J. \& Bharucha, Z.P. 2014. Sustainable intensification in agricultural systems. Annals of Botany, 114, 1571-1596.

15. Simamora A.P. Stop converting peatlands, govt study recommends. The Jakarta Post, Jakarta; 2010 [http://www.thejakartapost.com/news/2010/01/18/ stop-converting-peatlands-govt-study-recommends.html], 18 January 2010.

16. Thorlakson, T., \& Neufeldt, H. 2012. Reducing subsistence farm- ers' vulnerability to climate change: Evaluating the potential contributions of agroforestry in western Kenya. Agriculture \& Food Security, 1, 15.

17. Waldron A., Garrity, D., Malhi, Y., Girardin, C., Miller, D.C., Seddon N. 2017. Agroforestry can enhance food security while meeting other sustainable development goals. Tropical Coservation Science, 10, 1-6. 